\title{
FORMS AND FUNCTIONS OF MARKET SQUARES IN SMALL TOWNS OF LOWER SILESIA
}

\author{
Zuzanna Borcz ${ }^{1}$, Irena Niedźwiecka-Filipiak ${ }^{2}$ \\ Wrocław University of Environmental and Life Sciences, \\ pl. Grunwaldzki 24 a, 80-363 Wrocław, Poland \\ E-mail: ${ }^{1}$ borcz@aqua.ar.wroc.pl; ${ }^{2}$ filipiak@ozi.ar.wroc.pl
}

Submitted 28 Jan. 2008

\begin{abstract}
In the paper market squares in small towns of Lower Silesia region are presented, their area does not exceed 1 ha. For the present work 15 localities were selected: 10 towns and 5 villages which formerly had civic rights. The variety of shapes of market squares mainly resulted from the fact that the towns were founded in a different way. Most of them were formed as completely new settlements, the so-called settlements "on a rough root", the other ones developed from boroughs or commercial villages.

It should be pointed out that the function of a market square is its crucial feature. In the course of time the market square in many towns underwent transformations of its function along with the loss of importance as the central place of a town. Today market places for wholesale as well as for retail trade are designed at other points of a town. An old market square remains till now as an imposing place, although it may also be used as a car park.

Concluding, it may be established that market squares played in the past and still play an important role in a town.

Keywords: market square, function, form, city center.
\end{abstract}

\section{Introduction}

The market square, called the heart of a town is to be found nearly in all settlements. Market squares exist also in some villages, this gives an evidence that in the past they had civic rights. The aim of the present investigation are the following problems:

- the existence or absence of the market square in localities;

- the compositional and architectural form of the market square;

- the market square in villages and small towns;

- either the market square plays the role of the central point of an urban system or a decay of this role is observed.

\section{Investigation methods}

Investigation was performed in the Lower Silesia region, in its geographical and historical shape. It is a terrain close to the West border of Poland.

In the paper selected towns in Lower Silesia region are presented, their market squares do not exceed 1.1 ha of area. These market squares are relatively small; for comparison purposes the market squares in Wrocław (650 thousand inhabitants, 3,7 ha), in Brzeg Dolny (14 thousand inhabitants, 1.4 ha) and in Oleśnica (39 thousand inhabitants, $1.24 \mathrm{ha}$ ) may be mentioned. For the present work 15 localities have been selected: 10 towns and 5 villages which formerly had civic rights. The number of inhabitants of 13 localities does not exceed 5 thousand, the others have 8.5 thousand (Borcz 1985; Knie 2007).

The chosen small towns and villages were considered in the aspect of their genesis and history. In the study the urban system was investigated, a special attention being paid to market squares as central points of towns. The architecture of the environment of the market square was analysed. These are the frontages and buildings situated in the centre of the market square; most often it is a town hall or a church, sometimes small architecture objects, e. g. a well or a monument. During the study an architectural and photographical inventory was made.

In the first part of the paper the types of market squares are characterized in their compositional and architectural aspect. These are market squares of the 
Specifications of investigated towns and villages (Knie 2007; Czerwiński 1999)

\begin{tabular}{|c|c|c|c|c|c|c|}
\hline No & $\begin{array}{l}\text { Name of town or village (name } \\
\text { before 1945) }\end{array}$ & $\begin{array}{l}\text { Town/ } \\
\text { village }\end{array}$ & $\begin{array}{l}\text { Number } \\
\text { of habitants } \\
\text { (thousand) }\end{array}$ & $\begin{array}{l}\text { Date } \\
\text { of obtaining } \\
\text { civic law }\end{array}$ & $\begin{array}{l}\text { Frontages } \\
\text { of market square }(\mathrm{m})\end{array}$ & $\begin{array}{l}\text { Area of market } \\
\text { square (ha) }\end{array}$ \\
\hline 1 & Bierutów (Bernstadt) & $\mathrm{T}$ & 5.1 & 1266 & $84 / 83$ & 0.70 \\
\hline 2 & Cieszków (Freyhau) & V & 2.1 & 1489 & $80 / 77$ & 0.62 \\
\hline 3 & Dobroszyce (Juliusburg) & V & 2.2 & 1603 & $100 / 80$ & 0.80 \\
\hline 4 & $\begin{array}{l}\text { Karłowice (Karlowitz) settle- } \\
\text { ment of Wrocław }\end{array}$ & $\mathrm{T}$ & - & 1928 & $80 / 66-80$ & 0.59 \\
\hline 5 & Mieroszów (Friedland) & $\mathrm{T}$ & 5.1 & 1223 & $90-100 / 75$ & 0.71 \\
\hline 6 & Niemcza (Nimptsch) & $\mathrm{T}$ & 3.6 & 1262 & $230 / 33$ & 0.76 \\
\hline 7 & Prochowice (Parchwitz) & $\mathrm{T}$ & 3.7 & 1250 & $107 / 45$ & 0.48 \\
\hline 8 & Prusice (Prausnitz) & $\mathrm{T}$ & 2.4 & 1287 & $88 / 83$ & 0.73 \\
\hline 9 & Radków (Wünschelburg) & $\mathrm{T}$ & 2.4 & 1320 & $87 / 62-75$ & 0.59 \\
\hline 10 & Srebrna Góra (Silberberg) & V & 1.5 & 1536 & $50 / 40,50 / 30$ & 0.2 and 0.15 \\
\hline 11 & Strupina (Stroppen) & V & 0.5 & 1446 & $82 / 60$ & 0.49 \\
\hline 12 & Sułów (Sulau) & V & 1.5 & 1411 & $87 / 37-50$ & 0.39 \\
\hline 13 & Środa Śląska (Neumarkt) & $\mathrm{T}$ & 8.5 & 1235 & $335 / 30$ & 1.05 \\
\hline 14 & Twardogóra (Festenberg) & $\mathrm{T}$ & 6.9 & 1293 & $100 / 110,100 / 70$ & 1.1 and 0.70 \\
\hline 15 & Wiązów (Wansen) & $\mathrm{T}$ & 2.3 & 1252 & $88 / 106$ & 0.94 \\
\hline
\end{tabular}

shape of a spindle or rectangle as well as market squares of an axial system and those situated in garden-city settlements.

The second part presents a discussion of the transformations of market square functions and their functional "relocation".

\section{Compositional and architectural form of market squares}

The urban systems mostly originated from the 13th to 15 th centuries, and in principle they have remained till today. Many small towns lost their civic rights after the Second World War. From the administrative viewpoint they continue to be villages, only a few of them returned to their former town character.

The variety of shapes of market squares mainly resulted from the fact that the towns have been founded in a different way. Most of them were formed as completely new settlements, the so-called settlements "on a rough root", the other ones developed from boroughs or commercial villages (Taylor 2007; Czarnecki 2003; Jastrząb 2002).
The first foundations of towns in Lower Silesia occurred at the beginning of the 13th century. Princes bestowing civic rights for settlements relied on various West-European laws, e.g. Magdeburg-law as well as on a modified law, the so-called Sroda-law in the case of Środa Śląska and of about fifteen other towns.

In the foundation process a new urban system was traced out, or during the development of a given town its plan underwent transformations. As the first step of the endowment of civic rights the market square was traced out as well as streets coming out of its several directions, mostly from corners, or from the centre of a frontage. Afterwards the shape of defenses and fortifications encircling the whole town was established.

\subsection{Market squares in towns descending from commercial settlements}

An example of a town formed from a settlement situated at the trade route is Środa Śląska. The name probably has its origin in the privilege of markets on Wednesdays (Wednesday it is Środa in Polish). Sroda Śląska obtained civic rights before 1214, at that time it 
was called Novum Forum, in German Neumarkt; this name was used till 1945. The market square in Sroda Śląska preserved its primary spindle form, the length of $335 \mathrm{~m}$ arising from the enlarged trade route being the main axis of the middle age urban system characteristic for old Polish commercial settlements (Chmelewski 2005; Czerwiński 1999).

In the middle of the market square the town hall is situated (Fig. 1).

In the North-West of the town the prince's castle was erected in 1232 and rebuilt in 1574; since the 19th c it exists no more. The town hall was built in the 15th $c$, it possesses a valuable polychromy from the 16th and 17 th centuries.

In 1985 the so-called "Środa treasure" was found, it consists of 35000 silver coins; in 1988 a precious golden diadem set with jewels from the 15th $\mathrm{c}$ was found along with hundreds of golden and silver coins.

In Środa Śląska two churches exist; the first one from the 13th c, rebuilt in the 14th c, belonged to Red Star Order of Knights, nearby the church the Gothic belfry, built as a fortified tower in the 14th c. The second Gothic church of the 14th c was rebuilt in the baroque style in the 17th $\mathrm{c}$. The third church of the 13th $\mathrm{c}$ is a valuable monument of the past in which the elements of the Roman style were found in 1965.

Środa Śląska was erected on the Magdeburg law which after a modification was used as a Środa-law. The

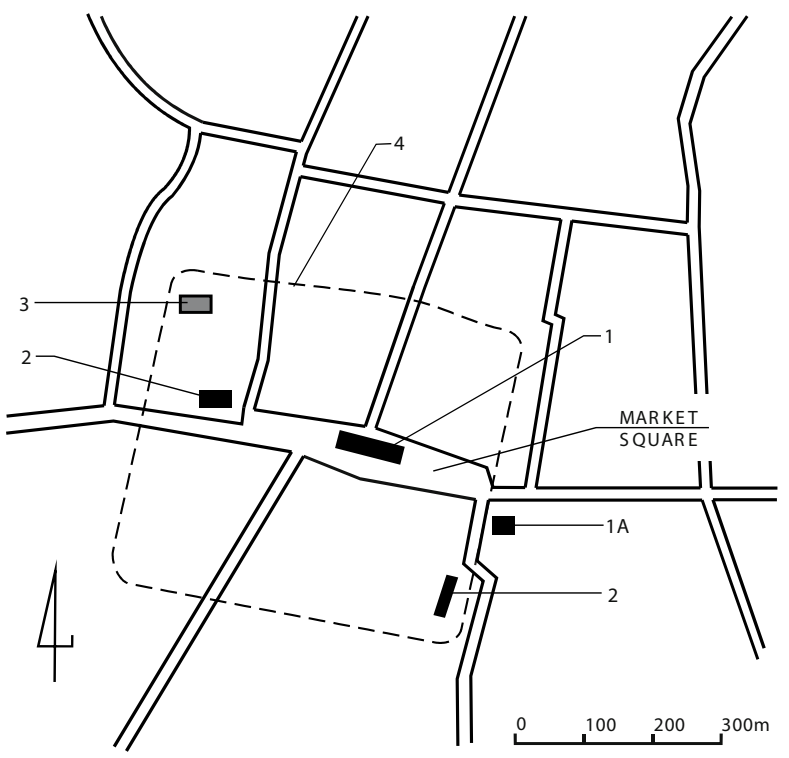

Fig. 1. Plan of Środa Śląska, town descending from commercial settlement: 1 - former town hall present historic museum, $1 \mathrm{~A}$ - new town hall; 2 - church; 3 - ruin of castle; 4 - battlements
Środa-law was accepted by numerous towns, such as Trzebnica, Olesnica, Sobótka, Kalisz, Opole.

Niemcza is another example of a town descending from an ancient commercial settlement. Similarly as in Środa Śląska, also in Niemcza, the long spindle-shaped market place $(230 \mathrm{~m})$ has remained till our times; it is situated on the hill slope. In the town fortifications two gates were erected: the upper one (South) and lower one (North). Niemcza obtained civic rights in 1262, they were confirmed by the Silesian prince Henryk Probus in 1282. In 1431-1434 the town was the largest Silesian Hussite centre. The old town is narrow and elongated due to the river-system. In the northern part of the old town a Renaissance castle existed, and in the southern part of the frontage of the market square a church with a tower (of $60 \mathrm{~m}$ ) was erected in the 19th $\mathrm{c}$ in the Neo-Roman style. In the market square frontage historic houses from the 18th to 19th $\mathrm{c}$ are to be found (Biesiekierski et al. 1999).

\subsection{Typical urban systems of small towns with central market squares}

As an example of a small town having a well-preserved urban system with a centrally-situated market square may serve Prochowice. Prochowice was founded in the 13th century on the trade route Wrocław - Głogów, nearby the mouth of the Kaczawa river to the Odra.

The town developed well in the 14th century, then a brick church was built, and the town was surrounded by defences. Since 1374 Prochowice possessed the exclusive right for salt commerce in the region. At the beginning of the 14th century a brick-castle was erected in the place of the former timber one. The present form of the castle has the Renaissance features of the 16 th century. In the course of years the town had its ups and downs, however, in spite of wars and pests it developed well.

In the centre of the town a rectangular market square $(107 / 45 \mathrm{~m})$ with six streets running from it is to be seen (Fig. 2).

The building of frontages is compact. Houses of a differentiated form date back to the 18-19th c (Figs. 3, 4).

The oldest house originates from 1588 and stands out from the frontage at several meters; it is the proof that in those days the market square was not so wide as it is now (Czerwiński 1999).

On the market square the town hall having the shape of a block with a hipped roof is situated. The first town hall was erected in the 14th century, the present 


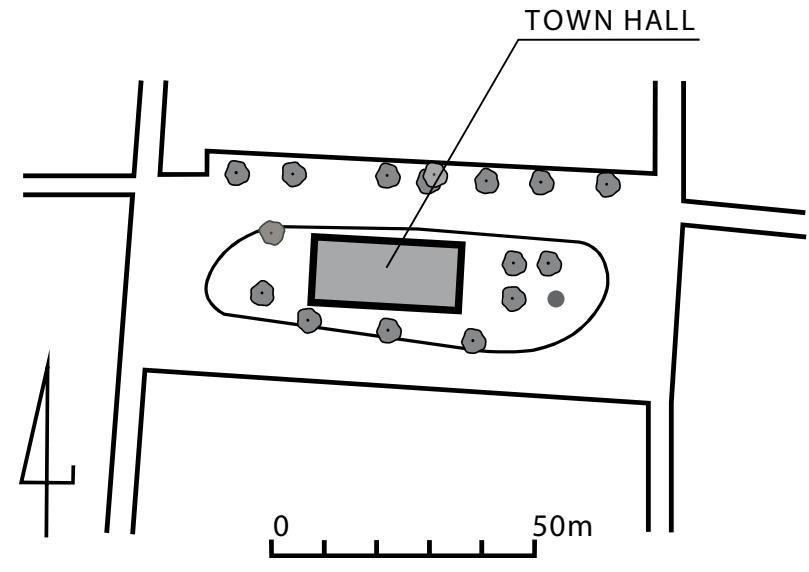

Fig. 2. Plan of market square in Prochowice town

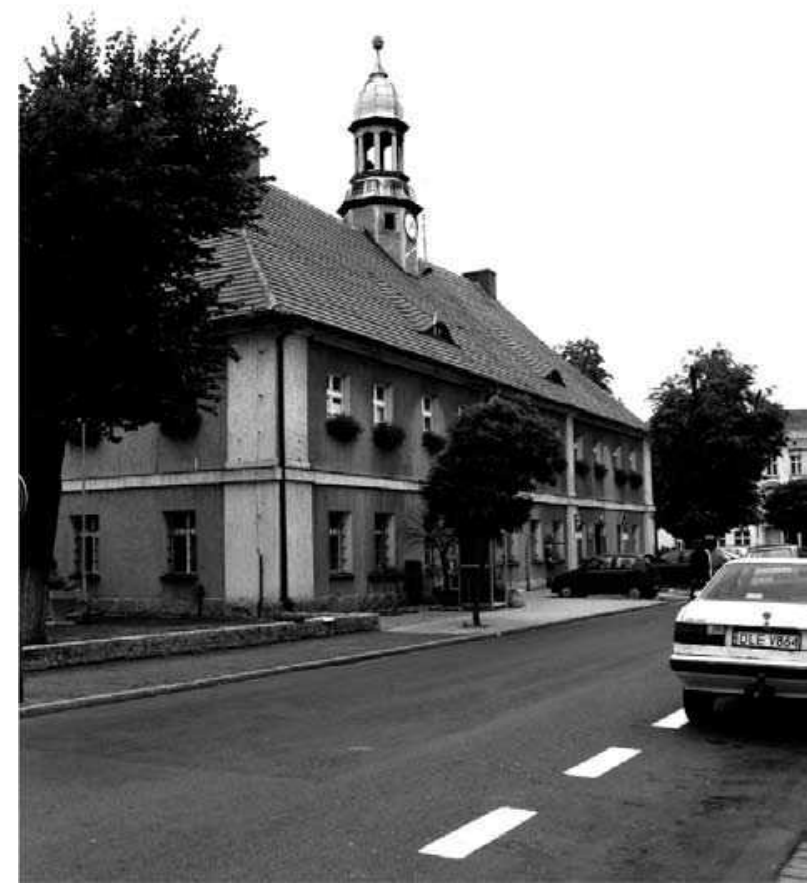

Fig. 3. Town hall on market square in Prochowice

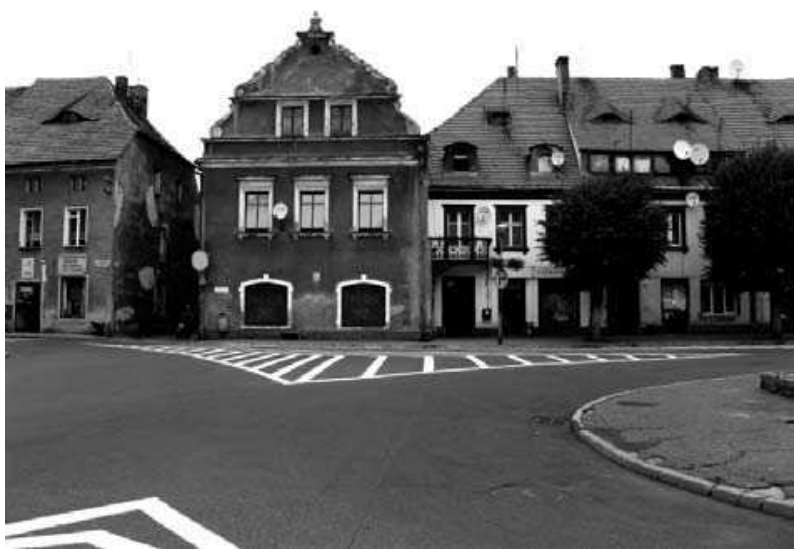

Fig. 4. Frontage of market square in Prochowice, to the left from a house of 1588 one dated from 1642 and was rebuilt in 1769; from this time dates the ave-bell with an open-work cupola. In the eastern part of the market square, nearby the town hall, several trees are planted, and in the western part a commemorative monument is situated.

In many localities which were founded as towns, after their development period a political or economic regress occurred, and as a result they have lost their civic rights. Such circumstances occurred especially after the Second World War, and often this state endures to our times. In such former small towns the urban system with a centrally situated market square and a network of streets has remained the same (Borcz 2003).

As an example of such a locality of an urban origin is Cieszków. In the 13th there existed here a castle, and Cieszków had a trade function; it obtained civic rights in the 14th century and lost them in 1841. From this prosperity period, there remained the system of streets, market square, two churches, railway station and remnants of the palace with the park. Both churches were endowed by princess Katarzyna Ludwika, the daughter of Jan Sapieha, the Great Hetman of Lithuania. The catholic church was erected in 1753 in the place of a wooden church of the $17 \mathrm{th}$, the second one was a Protestant church. After a fire in 1826 it was rebuilt in the Neo-Gothic style, this church exists in the West frontage, and three other frontages are built with twostorey dwelling houses (Czerwiński 1999). The market square of $80 / 77 \mathrm{~m}$ dimensions is bordered with lime trees, and in the middle a lawn is located (Fig. 5).

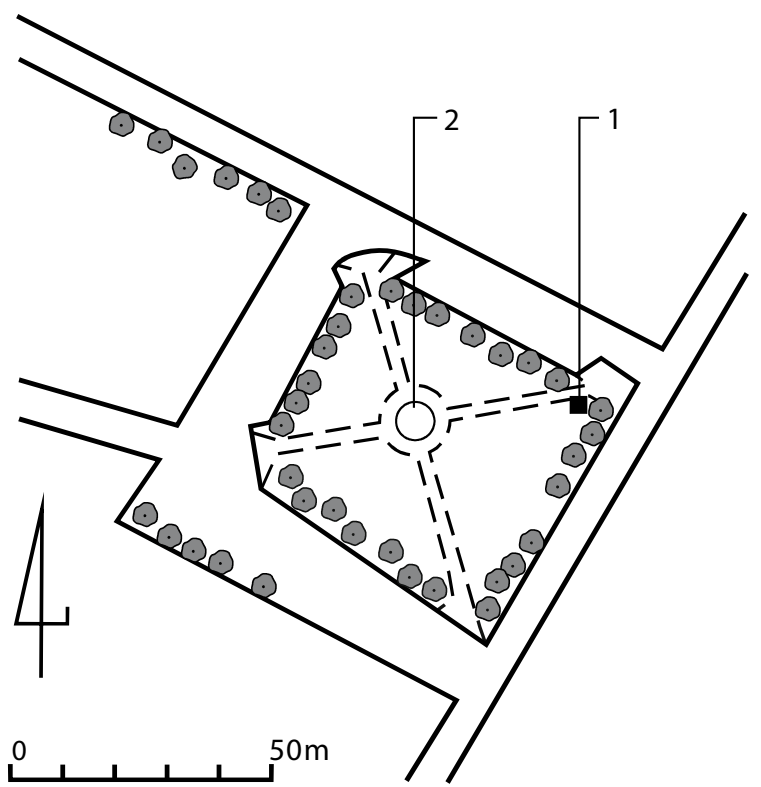

Fig. 5. Market square of Cieszków town (actually a village), surrounded by lime trees 


\subsection{Market squares and squares axially situated in relation to the town plan}

Twardogóra is an example of the town in which two market squares are axially situated in relation to the town plan; here there exists a distinct compositional axis connecting the church with the palace. Two big market squares are situated along this axis - the Upper and the Lower Markets. Twardogóra is located on the terrain of a slight slope, hence the names of both market squares (Fig. 6).

In the Upper Market the church is a central building, while the Lower Market is located in the neighborhood of the palace surrounded by a park. In the Lower Market the ancient building remained, the town hall existed formerly in one of its frontages. After destruction of this building, the town authorities moved to the former law court edifice centrally situated on the market square (Czerwiński 1999).

A similar system is found in Srebrna Góra which lies in the submontane region near the mountain sadle. The town came into being as a mining settlement in the 14 th century owing the name to the existence of silver ores (silver it is srebrna in Polish). Civic rights were given to Srebrna Góra in 1536. Due to its location the town became a strategic place, and military operations often destroyed Srebrna Góra. In the 18th c during the

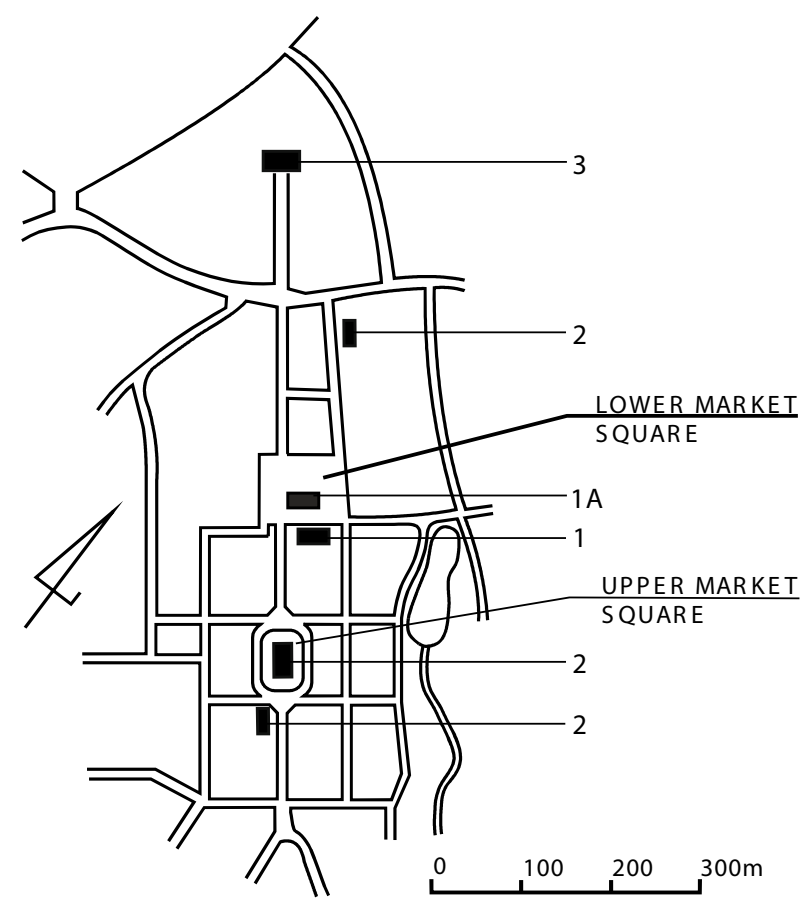

Fig. 6. Plan of Twardogóra town with axial urban system with two market squares: 1 - former town hall; $1 \mathrm{~A}$ - present town hall; 2 - church; 3 - palace reign of Frideric II the erection of big fortified works began (1765-1766). Today the citadel and fortifications remain in a good condition. The town had a specific urban system: houses were built in three rows, along them two streets stretched - Summer-street 'with elevations looking towards the South and Winter-street with North-facing windows. Between them an elongated market square and two squares are situated in terraces on the hill slope (Borcz 1985, 2003).

\subsection{Market square in satellite garden-city}

Completely different in view of its tradition is the market square in Karłowice settlement situated within the limits of Wrocław. At the beginning of the 20th century in town planning the trend for development of garden-cities played an important role. This idea was presented by the Englishman Ebenezer Howard (Levy 2006; Gregor et al. 2006) who saw the pollution and congestion of the 19th c towns and wanted to create a "garden-city', i.e. the city of a healthful environment, close to nature. This idea has found a reflection during the development of settlements around Wrocław, such as Karłowice, Pawłowice or Biskupin.

Karłowice was a settlement bound with Franciscan order and church. The plan of Karłowice enclosing the system of streets was worked out so early as in 1911, however, for the shape of the market square and for its building, an architectural competition was proclaimed in 1913 (Fig. 7).

In 1928 the settlement of Karłowice with its already formed urban system, market square and streets of relatively uniform buildings, along with a water-tower was incorporated into the town of Wrocław (Kononowicz 1997).

The market square of Karłowice has almost a rectangular shape, dimensions of 80/74 $\mathrm{m}$ and an area of 0.59 ha. It is surrounded from three sides by frontages of three-storeyed dwelling houses. The fourth frontage consists of two big decorated buildings having a different form and function than the other one (Figs. 8, 9). They are bound together by the annex and fence of a behind-located park. In the annex the show room exists. All the buildings surrounding the market square have tiled gable roofs of the same slope. The front elevations are plastered; above the entrances they are decorated with cornices and small bas-reliefs. The square is paved and encircled with a side-walk; in the middle the place bordered with trees and shrub hedge is to be seen. 


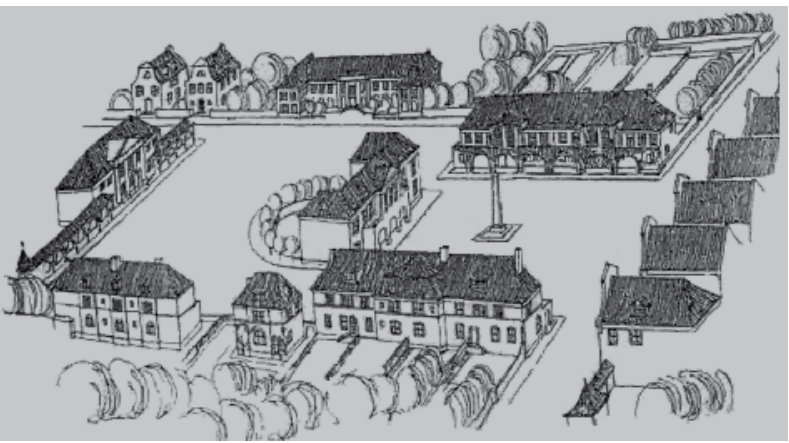

Fig. 7. Bird's view of market square in Karłowice, architectural competition in 1913

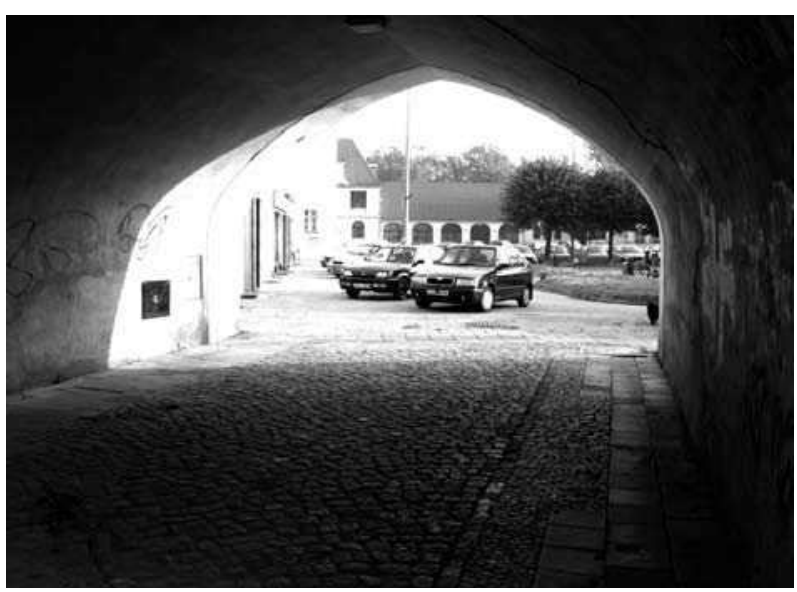

Fig. 8. Actual view of market square in Karłowice (since 1928 settlement of Wrocław town)

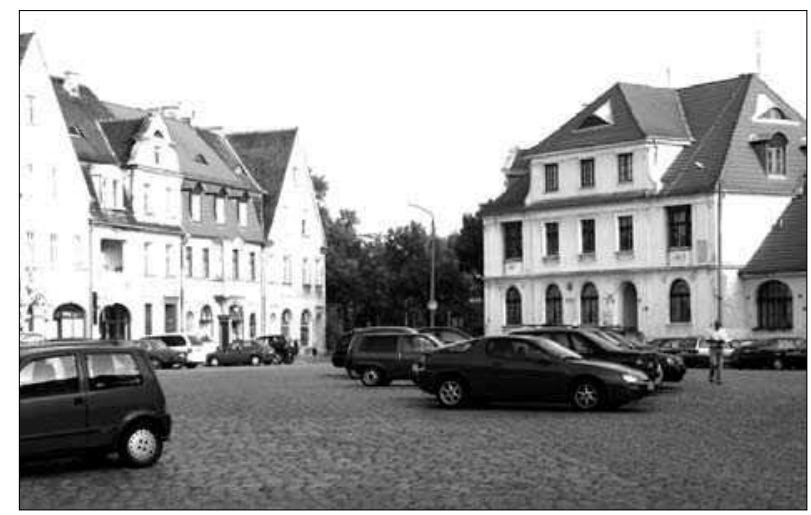

Fig. 9. Present frontage of market square in Karłowice

\section{Transformations of market square function}

It should be pointed out that the function of a market square is its crucial feature. In the course of time the market square in many towns underwent transformations of its function along with a loss of the importance as the central place of the town.

Although the market square is still situated in the centre of the town sometimes it appeared that due to the urban spatial development the market square along with its ancient frontages and buildings retired into the background; Strupina village may serve as an example. The present-day market square is no more a central market place. In the market square and its neighborhood horse-drawn carts are no more to be found as well as stands where in the past the townswomen came to buy agricultural and craft goods directly from their producers (Borcz 2003).

Today market places for wholesale as well as for retail trade are designed at other points of the town. An old market square remains till now as an imposing place, although it may also be used as a car park. In order to restore the importance of a market square, in its frontages shops and cafés should be established. A convenient solution are the arcades around the market square with the town hall in the middle.

The transformation of the function of the market square can be observed in the case of the mentioned Karłowice settlement. The small market square, existing already for almost 80 years, in recent time significantly lost its importance.

Its situation has not changed, it is located in the middle of a large settlement of the two- and three-storeyed buildings. Up to the seventees of the 20th century the shops of different trades, such as grocery, drugstore, paper-trade and shoe shops, as well as the pharmacy, located in the market square, have been doing well (Antkowiak 1997).

In 2000 in an adjacent street a new block of buildings was erected; it possesses two big modern shops, pharmacy and kiosk; nearby bus stops are situated. In a very short time a shift of the trade-communication center occurred; the former market square has become a place with weakly prospering shops, while the new center is flourishing.

It happens that from a market square, as a result of war damages, only ruins and the outline of a market square were left. After rebuilding, in frontages dwelling houses without shops are to be found, whereas trade and services are in the adjacent street. In the rebuilt market square often in one frontage the new town council building is located, before the lawn and the place for shows and ceremonies are to be found. The town of Koszalin is an example of such a design.

\section{Conclusion}

Market squares of small towns having up to 5 thousand inhabitants are 0.5 to 0.8 ha large, and the fronta- 
ges have the length of 80 meters. In most cases in the middle of a market square the town hall is situated, e.g. in Prochowice, Prusice, Radków, Wiązów; sometimes the town hall is located in one of the frontages, for example, in Twardogóra or in Niemcza. In the case of the destruction of the town hall, a chosen building serves as a seat of authorities.

The town-hall building, which is traditionally connected with the market square, in the course of time has also changed its function. The community or town authorities in most cases move to a new larger building, and in the former, often antique town hall a museum or conference rooms are arranged. To the installation of the market square belong a suitable pavement, the greenery of trees and shrubs with benches, sometimes a well or a fountain.

It may be concluded that market squares played in the past, and still should play an important role in a town. It is not essential if market square is located in the geometrical centre of the town. The market square is especially important in small localities where it may serve as a place of social meetings. The proportions of a small market square fit well the inhabitant scale and the height of buildings.

\section{References}

Antkowiak, Z. 1997. Wrocław od A do Z. Wrocław: Ossolineum.

Biesiekierski, T.; Suchodolski, J.; Trocka-Leszczyńska, E. 1999. Architektura na obszarze Sudetów / Architektur in der Sudetenregion. Wrocław: Wydawnictwo Politechniki Wrocławskiej.

Borcz, Z. 1985. Funkcje pozarolnicze wsi dolnoślaskiej [Unagricultural functions of the Lower-Silesia villages]. Wrocław: Wydawnictwo Akademii Rolniczej, 23-28.

Borcz, Z. 2003. Transformation of urban system of small towns in Poland, Architektura \& Urbanizmus 37(1-2): 15-22.

Chmielewski, J. M. Teoria urbanistyki w projektowaniu $i$ planowaniu miast. Warszawa: Wydawnictwo Politechniki Warszawskiej.

Czarnecki, B. 2003. Plac rynkowy współczesnego małego miasta $w$ Polsce. Białystok: Wydawnictwo WSFiZ.

Czerwiński, J. 1999. Dolny Śląsk. Warszawa: Muza.

Jastrząb, T. 2002. Place i rynki jako zagadnienie urbanistyczne. Poznań: Wydawnictwo Politechniki Poznańskiej.

Knie, J. 2007. Alphabetisch-statistisch-topographische Übersichtder Dörfer, Flecken, Städte und andern Orte der Königl. Preuss. Provinz Schlesien, Breslau.

Kononowicz, W. 1997. Wrocław, kierunki rozwoju urbanistycznego w okresie międzywojennym. Wrocław: Wydawnictwo Politechniki Wrocławskiej.

Mc Gregor, D.; Simon, D.; Thompson, D. 2006. The Peri-Urban Intergace. London: EARTHSCAN.
Levy, J. M. 2006. Contemporary Urban Planning. New Jersey: Pearson Prentice Hall.

Taylor, G. 2007. Urban Geography. London and New York.

\section{MAŽŬ ŽEMUTINĖS SILEZIJOS MIESTELIŲ FORMOS IR FUNKCIJŲ TYRIMAS}

\section{Z. Borcz, I. Niedźwiecka-Filipiak}

Santrauka. Pateikiami Žemutinès Silezijos miestelių istorinių turgaus aikščiu raidos ir šiandieninès situacijos tyrimo rezultatai. Tyrimui buvo parinkti charakteringiausi 1 ha ploto neviršijančiu 10 miestelių ir 5 kaimo gyvenviečių, anksčiau turejjusių civilinių teisių, pavyzdžiai. Šio tyrimo tikslas - atskleisti aikščių, praradusių prekybos paskirtį, raidos tendencijas šiandieninès miestų kultūros ir urbanistinès plètros kontekste. Autorès nagrinèja miestelių turgaus aikščių atsiradimo ir formavimosi urbanistines ir socialines prielaidas, atskleidžia funkcinio konteksto poveiki istoriniam aikštès plano pavidalui ir orientavimui erdveje, jos architektūrinei kompozicijai. Išryškinami nagrinèjamų aikščių kompoziciniai ryšiai su kitomis svarbiomis visuomeninèmis erdvėmis ir architektūrinèmis dominantèmis. Aprašoma turgaus aikščių funkcinė transformacija, vykusi XX a. Daroma išvada, kad buvusių turgaus aikščių lokalizacija miestelio centre ir jų meninè kompozicinè, taip pat ir istorinè vertè nulèmè tai, kad aikštės ir šiandien tebèra svarbios visuomeninès erdvès.

Reikšminiai žodžiai: turgaus aikšte, funkcija, forma, miesto centras.

\section{ZUZANNA BORCZ}

Dr Habil (architecture)(since 2000), Prof., Institute of Landscape Architecture, Wrocław University of Environmental and Life Sciences, pl. Grunwaldzki 24 a, 80-363 Wrocław, Poland, tel.+48(0 71) 32018 48,e-mail: borcz@aqua.ar.wroc.pl

Research interests: architecture of villages and small towns, spatial planning of suburban zones, landscape design.

\section{IRENA NIEDŹWIECKA-FILIPIAK}

Dr (architecture) (since 1999), lecturer, Institute of Landscape Architecture, Wrocław University of Environmental and Life Sciences, pl. Grunwaldzki 24 a, 80-363 Wrocław, Poland, tel. +48 (0 71) 32018 59, e-mail: filipiak@ozi.ar.wroc.pl

Research interests: spatial and functional set of villages, architectural order, village and small-town landscape shaping in favor of the cultural heritage, water in landscape. 